\title{
24. 開発途上国における低コスト・省エネルギー浄水システムの研究 \\ STUDY ON THE LOW COST AND THE ENERGY-SAVING WATER-TREATMENT SYSTEM IN A DEVELOPING COUNTRY
}

\author{
奈良 松範* \\ Matsunori NARA*
}

\begin{abstract}
According to the report of the United Nations (1998), one child has died at a time at 8 seconds owing to water-related illness, $80 \%$ of sick cause in a developing country is sewage, and there is no sewer institution in $50 \%$ of world population. 2,500 million people who cannot drink safe sterilized water exist in the world. The way things stand, a situation is getting worse steadily. In this research, experimental examination was performed about the method for manufacturing water simple and cheap, and safe in view of a water shortage in a developmental-stage area, and the point that safe water is not supplied especially. Consequently, the thin laminar flow multi-stage processing process of having used the photocatalyst was developed as the suitable water purification method for a developing country. According to this method, the coliform bacteria count was removed by the conditions of $1 \mathrm{~cm}$ in thickness of thin laminar flow, and $7 \mathrm{~cm}$ of distance with a light source $100 \%$ in 5 hours after a processing start for holding time 3 hours. In order to evaluate water quality purification performance, the COD reduction which is a water pollution index, and the coliform bacteria count which are the health of water and the index of safety were examined.
\end{abstract}

KEYWORDS ; Water treatment system. Low cost, save energy, a developing country

1.はじめに

地球上の人口は、1950 年に約 25 億人であったものが、2006 年 2 月 25 日午後 7 時 16 分(米国東部標準時) に 65 億人を突破する（米国勢調査局の『世界人口時計』）という。人口の急増には目を見張るばかりである。 そして、世界の人口の 2 割は先進地域、残りの 8 割は開発途上国に住んでいる。すなおち、人工の急激な增 加およびこれに伴う産業の著しい発展による水需要の増大は、開発途上地域で顕著であり、現在、アジア、 アフリカなど 31 の国が水の絶対的な不足に悩んでいる。また、下水道等の施設整備が追いつかない途上国を 中心に著しい水質污染が問題となっており、国連（1998年）の報告によれば、水関係の病気で、子供たちが 8 秒に 1 人ずつ死亡しており、途上国における病気の $80 \%$ の原因は污水であり、そして世界人口の $50 \%$ に、、 下水施設が未整備である。消毒した安全な水を飲めない人々は、世界で 25 億人存在する。このままでは状況 は悪化する一方である。本研究では、開発途上地域における水不足、特に、安全な水が供給されていないと いう点に鑑み、簡易かつ安価で安全な水を製造するために方法について実験的検討を行った結果、適当な水 浄化方法として、光触媒を用いた薄層流多段処理プロセスを開発した。水質浄化性能を評価するため物質と して、水質污濁指標であるCOD（化学的酸素要求量）の低減および水質の健康安全性の指標である大腸菌 群数と用いた。本法によれば、光触媒が発生するヒドロキシラジカルの強い酸化分解作用により有機污染物 諏訪東京理科大学システム工学部

Tokyo University of Science, Suwa 
質を分解除去することは容易であったが、他方で、この酸化分解力により発生する光触媒担体のチョーキン グ現象の防止が大きな課題であった。また、飲料水であることから、短時間に大量の水を効率的に処理する ための設計パラメータを明らかにすることが要求された。結果として、ゾルゲル法によりチョーキングの防 止、および薄層流プロセスの採用により、効率的な水質浄化が可能となったので報告する。

\section{2. 方 法}

薄層流循環式処理システムにおいて、光触媒である二酸化チタン（TiO2）を用いることにより、水質の浄 化および殺菌を行うことを目的に、最適な処理条件を明らかにするために、基礎的な実験を行った。

\section{1. 二酸化チタン}

二酸化チタン: titanium dioxide 化学式 $\mathrm{TiO}_{2}$ 、分子量 79.9 、白色粉末、正方晶系、比重 3.8 4.1 (ルチ ル型)、3.9〜4.2 (アナターゼ型)、融点 $1,858^{\circ} \mathrm{C}$ 、屈折率 2.71 (ルチル型)、2.52 (アナターゼ型)、食品添加 物としても認められており安全な材料である。本材料は、絵具、クレヨン、歯科材料、石鹸等に広く使用され ている。酸化チタンはアナターゼ、ルチルともに弗酸、熱濃硫酸および溶解アルカリ塩に溶解するが、それ 以外の酸、アルカリ、水、有機溶媒などには溶解しない。酸化チタンはこのように特殊な条件下では他の物 質と反応することはあるが、通常の使用条件ではきわめて安定しており、燃焼、暴発などの危険性はない安 全なものである。常圧・常温下では $\mathrm{HF} 、 \mathrm{SO}_{3} 、 \mathrm{Cl}_{2} 、 \mathrm{H}_{2} \mathrm{~S}$ など反応性の強いガスと酸化チタンは反応するこ とはないが、高温では $\mathrm{HF}$ と反応し $\mathrm{TiF}_{4}$ となる。さらに還元剤が共存する中の高温状態では、 $\mathrm{Cl}_{2}$ など八ロ ゲンと反応し $\mathrm{TiCl}_{4}$ など八ロゲン化チタンを生成する。また高温下、 $\mathrm{H}_{2} 、 \mathrm{CO}_{2}$ などで還元されて低次酸化物 に変化する。製造工程上では硫酸法も塩素法も、800 $1100^{\circ} \mathrm{C}$ 熱処理を経ているため、酸化チタン自身は $800^{\circ} \mathrm{C}$ 以下の加熱による変質は本質的にない。ところで、チタン原料を基材上で直接結晶化して酸化チタンと する以外はほとんどの場合、酸化チタンとバインダー等を含有するコーティング材を基材に塗布することで 光触媒の機能を付けることになる。しかし、いつも使用している塗料で用いられ有機系のバインダーでは、 光触媒酸化チタンの持つ強い酸化力により、短期間でチョーキングなどの劣化が起こるため、酸化に強い無 機系のバインダーの使用が必要となる。そこで、本研究では、ゾル-ゲル法を用いた。ゾル-ゲル法は、金属 アルコキシドのアルコール溶液を出発原料として、溶液中の化合物の加水分解・重合によって溶液を金属の 酸化物あるいは、水酸化物の微粒子が溶解したゾルとし、さらに反応を進ませてゲル化を得る方法である。 二酸化チタン結晶の成膜にあたってゾルゲル法を適用するには、アルコキシドを水に溶解させて加水分解し、 溶液を調製する手法を採用した。反応において、チタンテトライソプロポキシド( 284.23)、アセチルアセト ン( 100.12)、エタノール(99.5)、エチルアルコール（46.07)、硫酸 $(=46.08) 、$ 硝酸 $(=63.01)$ を使用した。

\section{2. 大腸菌群数の測定}

本研究で採用した特定酵素基質培地法は、大腸菌群の乳糖発酵性に関与する $\beta$ ーガラクトシターゼの有無 で大腸菌群を判定する方法である。 $\beta$ 一ガラクトシターゼ活性を調べる酵素基質には、ON P G（oーニト ロフェニルー $\beta$-Dーガラクトピラノシド）及びX G a 1 （5-ブロモー4-クロロー3.-インドリルー $\beta$ 一Dーガラクトピラノシド）があり、それぞれガラクトピラノシドの分解により遊離した発色物質で判定す る。用いる酵素基質により ON P G 法、X Gal 法に分かれる。なお、両方とも大腸菌が同時に判定できるよ う MUG（4ーメチルウンベリフェニルー $\beta$-D-グルクニド）が含まれている。大腸菌培地(コンパクトドラ イ「ニッスイ」CF 日水製薬株式会社)を使用した。

\section{3 . 化学的酸素要求量 $\left(\mathbf{C O D}_{\mathbf{M n}}\right)$}

污染された水中に存在する污濁物質の量を定量化するために、COD を用いた。COD 以外にも污濁指標と なる測定項目は多々あるが、多数の検体を処理する必要があることから、測定が短時間で済むこと、および 測定方法が簡易であること等を勘案して COD を選択した。COD は「下水道試験法」にしたがい、“ $100{ }^{\circ} \mathrm{C}$ における過マンガン酸カリウムによる酸素要求量”を測定した。 


\section{4. 光エネルギー光量}

光触媒を反応させるためには近紫外線が必要であり、太陽光には一般に全体の $3 \%$ 集外線である。光触 媒反応に必要な波長 $380 \mathrm{~nm}$ 以下の紫外線であり、実験で効率的に得るにはブラックライトを使用する。ブラ ックライトから照射された光は実際に減少するため酸化チタンに当たり光触媒反応が起こるまでには光源と は光量が減少している。よって酸化チタンに当たる紫外線量を計算するには以下の式を用いる。

$$
W \times \frac{\theta^{\circ}}{360^{\circ}} \times \frac{D}{A}
$$

ここで、W:ワット数、 $\mathrm{D}$ :タイルまでの距離、 $\mathrm{A}$ : 水面積、 $\theta$ : 光軸の傾き角

2. 5. 薄層流循環システム
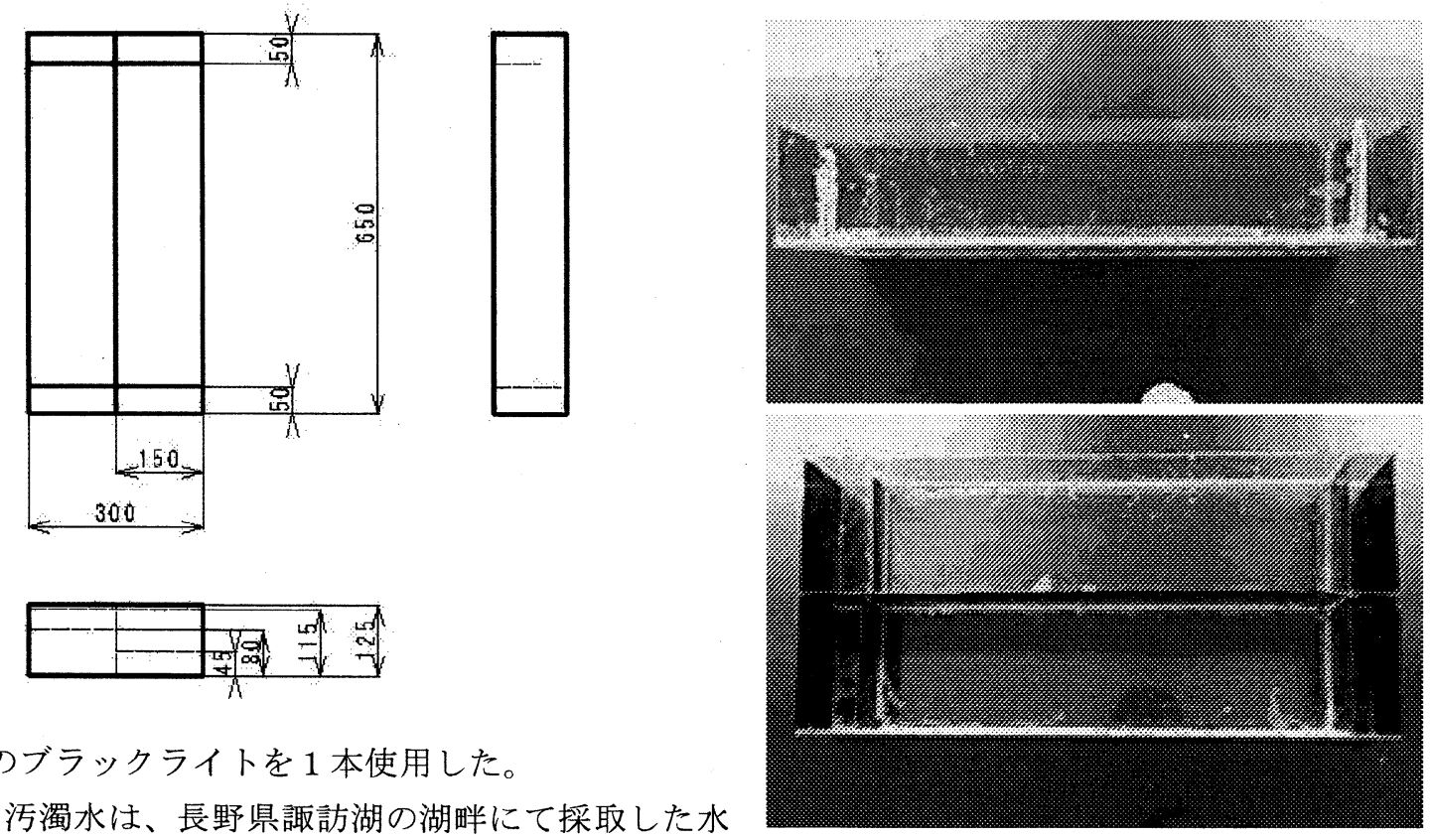

光源は $20 \mathrm{~W}$ のブラックライトを 1 本使用した。
実験に用いた污濁水は、長野県諏訪湖の湖畔にて採取した水 を用いた。なお、実験に用いた水は、毎回の実験に先立ち、 その日の朝に採水し、同日中に使い切り、水質が環境中で酸 化することによる影響を最小限に抑制した。また、送水によ る水質浄化および大腸菌除去実験は以下の手順で行った。

1. 暗室内に水槽を置き、水槽にタイルを敷きサンプル の水をはる。この水槽は弐連式である。片方にはコーティン グしていないタイル敷く。

2. 水を循環させるために送水を行う。滞留時間は、1 時間、3 時間、6 時間である。

3. (1)、(2)と同じことを水位と光源から板までの距離を 変えて行う。変化させる水位は、 $3 \mathrm{~cm} 、 5 \mathrm{~cm} 、 1 \mathrm{~cm}$ 老行う。変 化させる光源から距離は、 $15 \mathrm{~cm} 、 10 \mathrm{~cm} 、 7 \mathrm{~cm}$ で行う。

\section{3. 結果および考察}

基礎実験として、水の流れがない場合について検討した結 果、固定した酸化チタン膜により 4 時間で完全に大腸菌を除 去することができた。このことから送水実験では滞留時間を

表 1. 薄層流循環処理における実験条件

\begin{tabular}{|c|c|c|}
\hline 水位 $[\mathrm{c} \mathrm{m}]$ & $\begin{array}{c}\text { 光源からの } \\
\text { 距離 }[\mathrm{c} \mathrm{m}]\end{array}$ & 留時間 $[\mathrm{h}]$ \\
\hline 1 & 7 & 1 \\
\hline 1 & 7 & 3 \\
\hline 1 & 10 & 1 \\
\hline 1 & 10 & 3 \\
\hline 3 & 7 & 1 \\
\hline 3 & 7 & 3 \\
\hline 3 & 7 & 6 \\
\hline 3 & 10 & 1 \\
\hline 3 & 10 & 3 \\
\hline 3 & 10 & 6 \\
\hline 3 & 15 & 3 \\
\hline 5 & 7 & 1 \\
\hline 5 & 7 & 3 \\
\hline 5 & 7 & 6 \\
\hline 5 & 10 & 1 \\
\hline 5 & 10 & 3 \\
\hline 5 & 10 & 6 \\
\hline
\end{tabular}


3 時間を中心に設定することにした。 これは静止水では水に動きがないた め実際より時間がかかったとも考え られたからである。滞留時間 1 時間 はある程度の流れを与えることを目 的とするとともに $1 / 3$ の時間で大腸 菌の除去が行えるかを検証するため に設定した時間である。滞留時間 6 時間は中心に設定した時間よりも 2 倍の時間にすることで除去効率も上 がると考えたからである。

\section{1 . 水質浄化性能}

本法の効果を水質の代表值として CODを用いて検討した結果を図 1 に示した。処理を開始して 3 時間後 には、二酸化チタンなしの場合、除 去率が $13 \%$ であったのに対して二 酸化チタンありでは $60 \%$ の除去率 であった。さらに、24 時間後には、 それぞれ $73.6 \%$ および $88.2 \%$ であっ た。このことから本法では、急速に 污染物質を分解することができる。

3. 2. 殺菌性能 (大腸菌群)

殺菌効果を表す大腸菌群数の減少 の傾向を図 2 に示した。二酸化チタ ン存在下では、処理開始後 3 時間で
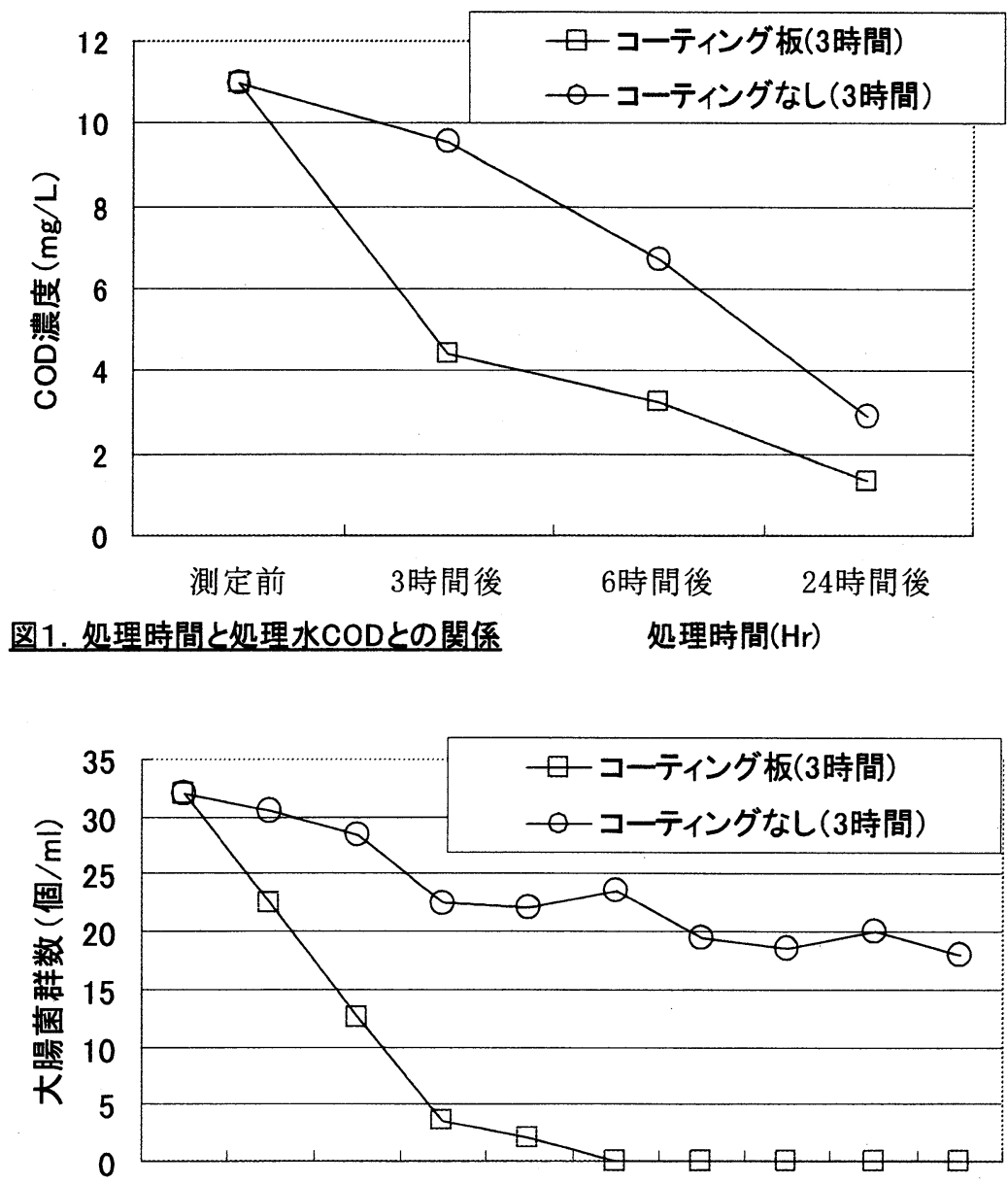

$89.1 \%$ の減少が確認され、 5 時間後には除去率は $100 \%$ であった。他方、 二酸化チタンがない場合には、処理後 3 時間で除去率が $29.7 \%$ 、24 時間 後でも $42.2 \%$ であったことから、本法の殺菌効果の高さが伺われる。さ らに、大きな特徵は、塩素あるいはオゾンによる殺菌では、処理後、菌 体の復活が観察され、大腸菌群数が増加する例が見受けられるのに対し て、本法では、処理後 24 時間後でも、大腸菌群数の再増殖は観察されな かった。さらに、CODおよび大腸菌群数の減少に寄与するパラメータ について調べて結果をそれぞれ表 2 および表 3 に示した。

\section{4. 結 論}

本研究により薄層流循環システムの設計パラメータを実験的に求める ことができた。方法では、酸化チタンという安価の材料に太陽光を当て るだけで、污濁水の浄化および大腸菌群数の減少（殺菌）の効果が得ら

\begin{tabular}{|c|c|}
\hline 水位 $\mathrm{cm}$ & -0. \\
\hline 滞留時間 h & 0. \\
\hline 光源までの距離 & 0.1 \\
\hline COD(除去後) & 0.0 \\
\hline 温度 (水温) & -0.57 \\
\hline $\mathrm{PH}$ & 0.0 \\
\hline
\end{tabular}

表 3. 大腸菌除去に関する 標準偏回帰係数

\begin{tabular}{|l|r|}
\hline 水位 $\mathrm{cm}$ & -0.61 \\
\hline 滞留時間 $\mathrm{h}$ & -0.09 \\
\hline 光源までの距離 & 0.59 \\
\hline $\operatorname{COD}$ (除去後) & -0.07 \\
\hline 温度(水温) & 0 \\
\hline $\mathrm{PH}$ & 0.08 \\
\hline
\end{tabular}
れることが示された。また、これはメンテナンスも容易であることから、開発途上国で要求されている安価 かつ維持管理の容易な水処理システムとして有用であることがわかる。まだ、いくつか改良すべき点もある が、今後、本システムの実用化に向けた研究を進めたい。

＜参考文献＞入門ビジュアルサイエンス“光触媒のしくみ”（藤嶋昭・橋本和仁・渡部俊也） 